\title{
An Empirical Examination of Feedback Effect in the Trade Relationship Between UAE and Trading Partners
}

\author{
Abdusalam F. Yahia
}

\begin{abstract}
This paper examines the feedback effect in the trade relationship between UAE and its three top trading partners (Japan, India and Mainland China). a simultaneous-equations model with double log form has been tested and used in order to analyse the role played by the interaction of trade and the degree of feedback effect. The results of the econometric model confirm that there is evidence of partial feedback effect in UAE trade with each of Japan and China. UAE's imports from its partner are subject to its income with a partial adjustment mechanism. the short-term elasticity of UAE imports with respect to its income seems to be higher (e.g. ranging from .70 to 1.8 ) in all cases .
\end{abstract}

Index Terms-Feedback effect, top trading partner, UAE.

\section{INTRODUCTION}

The UAE economy is a developing small open economy in the Arabic Gulf Region with distinguished oil and gas resources, and a significant trade surplus. In fact, foreign trade plays an important role in determining the level of economic growth in the UAE. The impact of foreign trade on the UAE economy can be explained through the mechanism of trade interdependence as follows: i) an increase in UAE exports from its trading partners results in an increase in its income .ii) the increase in UAE imports represents an increase in the incomes of those countries that exports to UAE .iii) this rise in the income of the exporter will, in turn stimulate demand, i,e. Increase its imports. This will result in an increase in the exports of the other partners.

The aim of this paper is to examine the feedback effect in trade relationship between UAE and its three top trading partners. Hence, the structure and the level of trade relationship between UAE and its three top major trading partners ( Japan, India and Mainland China) during the period 1997-2010 was tested in this paper.

The reminder of paper is structured as follows; after the introduction, section two gives a brief review of related literature. Section three is an illustration of the magnitude of trade between UAE and its trading partners. A simultaneous equations model is developed in section four to analyse the feedback effects between UAE and its three top trading partners. Section five discusses the results of the regression model. The final section provides some concluding remarks.

Manuscript received October 14, 2012; revised November 20, 2012

A. F. Yahia is with department of economics, faculty of economics and commerce, Almergibe University, Al- Kumis, Libya (e-mail: asuprince2000@yahoo.com ).

\section{A BRIEF REVIEW OF THE LITERATURE ON FEEDBACK EFFECTS OF FOREIGN TRADE}

The literature on feedback effects of foreign trade has increased during the past two decades, one my mention to work by [1]-[4]. Metwally and Vadlamudi developed a simultaneous equation model in order to examine if there is a feedback effect of the trade relationship between Australia and fifteen Middle-Eastern countries during the period between 1971 and 1988. Their model consists of seven endogenous and four exogenous variables. They found that Australian GDP was not affected by its imports from Middle-Eastern countries, and there was no feedback effect due to the fact that the participation of Middle Eastern countries in Australian market is very small [1].

Reference [2] shows that Based on the hypothesis that "exports lead to growth" Ardakani applied a simultaneous equations model in order to analysee trade relationship between Iran and its top trading partners. The main findings confirm that Iranian income has been significantly affected by the exports of its major trading partners. more, it indicates that Iranian oil revenue has been essentially influenced by the changes in oil prices. Moreover, exports have applied positive and extend impact on the rest of Iranian economy.

Reference [3] examined the feedback impacts in GCC countries with its trading countries during the period from 1970-1996. The author applied the simultaneous equation model in order to examine the procedure of trade interaction between GCC and the rest of the world. The major results of the study indicate that there is a significant feedback impact in GCC trade with its major trading partners namely the USA, the EU and Japan.

The trade relationships between Libya and its major trading partners has been tested in reference [4] and the main results indicated that The level of Libyan imports from its major trading partners does not seem to have any significant effect on the level of GDP of its major trading partners except Greece, Tunisia and Turkey.

\section{The DiRECTION OF TRADE OF THE UAE}

The behavior and the magnitude of UAE foreign trade with its trading partners during the last five years of this study is illustrated in table one. it shows that the UAE trades mostly with Asian Countries, Germany, the U.S.A and the UK. For example, approximately 47 per cent of the UAE exports are directed to these countries. In fact, more than 38 per cent of UAE exports were absorbed by five of these countries (Japan, The USA, China, S. Korea, and India). A glance at 
data in table one shows that over $72 \%$ of UAE imports were supplied by Asian countries, Germany, the U.S.A and the UK. Once again, more than 56 per cent of UAE imports were supplied by only five of its major trading partners (Japan, The USA, China, S. Korea, and India). Individually, the data table one seem to suggest that the largest importer of UAE goods are Japan $(19.23 \%)$ followed by India $(8.2 \%)$ in the last five years of this study. In the meantime, India is the largest exporter to UAE $(16.9 \%)$ followed by China $(15.99 \%)$ and the USA (11.93).

TABLE I: THE UAE TRADE WITH ITS MAJOR TRADING PARTNERS

\begin{tabular}{|l|c|c|c|}
\hline Country & $\begin{array}{c}\text { \% of total } \\
\text { UAE } \\
\text { Exports }\end{array}$ & $\begin{array}{c}\text { \% of total } \\
\text { UAE } \\
\text { Imports }\end{array}$ & $\begin{array}{c}\text { Total of } \\
\text { exports and } \\
\text { imports as } \\
\text { percentage** }\end{array}$ \\
\hline Germany & $\mathbf{0 . 3 4}$ & 7.8 & $\mathbf{8 . 2 3}$ \\
\hline Japan & 19.23 & 7.17 & 26.4 \\
\hline Korea S & 7.78 & 4.24 & 12.02 \\
\hline UK & 1.06 & 6.93 & 7.99 \\
\hline USA & $\mathbf{0 . 9 1}$ & 11.93 & 12.84 \\
\hline China & 1.92 & 15.99 & 17.91 \\
\hline India & $\mathbf{8 . 2 6}$ & 16.9 & 25.16 \\
\hline Iran & 7.38 & 0.73 & 8.11 \\
\hline $\begin{array}{l}\text { Total of } \\
\text { Partners }\end{array}$ & 46.88 & 71.69 & \\
\hline $\begin{array}{l}\text { The rest of } \\
\text { the world }\end{array}$ & $\mathbf{5 3 . 1 2}$ & 28.31 & \\
\hline Total & 100 & 100 & \\
\hline Sour & & & \\
\hline
\end{tabular}

* Source: prepared by the author and based on data from IMF and AMF databases.

**The criterion is that any country trades with UAE more than $15 \%$ (exports +imports) is defined as top trading partner.

\section{The Structure OF THE MOdEL}

Drawing upon the existed literature and following [4], [5] method, the following simultaneous equation model is developed and specified in order to analyse the interaction of trade relationships between UAE and its three top trading partners and to test if there is any feedback effect.

\section{Simultaneous-Equations Model}

$\ln Y E_{, t}=\alpha_{0}+\alpha_{1} \ln X E_{\text {Partner }, t}+\alpha_{2} \ln X,,_{, t}+\alpha_{3} \ln Y E_{, t-1}$ $+\varepsilon_{1 t}$

$\ln X E_{\text {Partner }, t}=\beta_{0}+\beta_{1} \ln Y_{\text {Partner }, t}+\beta_{2} \ln \mathbf{M E}_{\text {Partner }, t}+\beta_{3} \ln$

$M E_{\text {Partner }, t-1}+\varepsilon_{2 t}$

$\ln M E_{\text {Partner }, t}=\delta_{0}+\delta_{1} \ln Y E_{, t}+\delta_{2} \ln M E_{- \text {Partner }, t-1}+\varepsilon_{3 t}$

The first equation tests the relationship between UAE GDP and its exports to each top trading partners. It is supposed that UAE GDP is depends on exports to top trading partner and as well as to the rest of the world. Equation 2 examines the mechanism of trade interdependence and tests for the feedback effects. Its assumed that the UAE exports to its top trading partner is a function of income of top trading partner and the UAE imports from its top trading partner. It is understood that, an increase in income of partner will results in an increase of their imports from UAE. If there is a significant feedback effect, we would expect the coefficients $\left(\beta_{2}\right)$ and $\left(\beta_{3}\right)$ to be statistically significant. For only then, would be save to conclude that increasing imports results, through the increase in the purchasing power of the top trading partners, in stimulating their imports from the UAE. [4], [5] .

Equation three completes the logical sequence for the feedback effect that the UAE imports from its top trading partner depend on the level of its GDP and the UAE imports from its partner in period $\left(\mathrm{t}_{\mathrm{t}-1}\right)$. The lagged dependent variable gives the equations a dynamic character, allowing for partial adjustment (or lagged effects) following a Koyck geometrically declining weight scheme [6], [7], [9].

Applying the order and rank condition, we find that the model has as many equations as endogenous variables and in this sense is mathematically complete and all three equations are over-identified. Therefore, Two Stage Least Squares (2SLS) is the suitable method in estimating the three equations of the model, [6], [9], [10].

\section{The DATA AND EMPIRICAL RESUlts}

The data in this paper covers the period from 1997-2010, and has been collected from [11]-[13] Databases to analyse the trade relationship between UAE and its three top trading partners . Eviews package was used to find out the estimators of all equations in the model.

As shown bellow, the three equations are suitable, as evident from the values of adjusted $\bar{R}^{2}$ and the " $\mathrm{t}$ " statistics (shown under each coefficient). In addition, for the period 1997-2010 the Durbin Watson (DW) statistic does not indicate any significant problem of serial correlation at the ten per cent level of significance. moreover, the model is appropriate as obvious by the fact that the $F$ test and the coefficients of the lagged variables lies between zero and one in all cases [7], [8].

Data in equation 4 shows the regression results for Japan. These results indicate that UAE income is strongly influenced by UAE exports to Japan and to the rest of the world. The " $\mathrm{t}$ " value of the coefficient of the variable "XE. Japan, $t$, which represents UAE exports to Japan, is significant at the five per cent level of significance. Further, assessment of the coefficient $(Y E, t-1)$ suggests the existence of a significant spread effects.

The results of the equation 5 suggest that The growth in Japan's income a positive influence on UAE exports to Japan. The coefficient $\beta_{2}$ which represents the impact of UAE imports to Japan is statistically significant, this suggests the partial feedback effect in UAE to Japan. This is evident from the fact that the value of UAE imports from Japan represents a large proportion of Japan's total exports (see Table I).

$$
\begin{aligned}
& \ln Y E_{, t}=0.59+0.16 \ln X E_{\cdot J a p, t}+0.45 \ln X E_{,_{0, t}}+0.38 \ln Y E_{t-1} \\
& \begin{array}{llll}
0.28 & 2.1 & 1.67 & 1.5
\end{array} \\
& \bar{R}^{2}=0.98 \quad \mathrm{~F}=284 \quad \mathrm{DW}=2.02 \\
& \ln X E_{\text {Jap }, t}=-10.2+0.89 \ln Y_{\text {Jap } i, t}+1.24 \ln \boldsymbol{M} E_{\text {Jap }, t}-0.50 M E_{\text {Jap }, i, t-1} \\
& \begin{array}{llll}
-0.8 & 1.01 & 4.4 & -01.7
\end{array} \\
& \bar{R}^{2}=0.84 \quad \mathrm{~F}=18 \quad \mathrm{DW}=1.9
\end{aligned}
$$

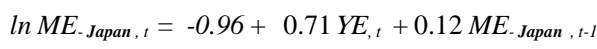

$$
\begin{aligned}
& \begin{array}{lll}
-0.87 & 3.5 & 0.55
\end{array} \\
& \bar{R}^{2}=0.87 \quad \mathrm{~F}=36 \quad \mathrm{DW}=1.7
\end{aligned}
$$


The regression results in the equation 6 suggest that UAE imports from Japan are positively dependent on GDP within a partial adjustment mechanism. The estimated coefficient $\delta_{1}$ represents the short-term elasticity, while the long-term elasticity is given by $\delta_{1} /\left[1-\delta_{2}\right]$, [14], [15] . The short-term elasticity of UAE imports from Japan with respect to UAE income is approximately .71, while its long-term counterpart is approximately .80 . This suggests that an increase in UAE income by $1 \%$ results in an increase in UAE imports from Japan by approximately $71 \%$ in the short term and by $80 \%$ in the long term.

The regression results for India (IND) are given in equation 7-9. These results in equation 7 suggest a weak relationship between UAE's income and its exports to India but a strong relationship between UAE's income and its exports to the rest of the world. The significant $t$ value of the coefficient of the lagged dependent variable suggests that there is partial adjustment mechanism in the income -export relationship between UAE and India .

$$
\begin{aligned}
& \ln Y E_{, t}=0.63+0.032 \ln X E_{-I N D i, t}+0.61 \ln X E_{0, t}+0.33 \ln Y E_{t,-1} \\
& \begin{array}{llll}
0.60 & 0.37 & 4.9 & 2.2
\end{array} \\
& \bar{R}^{2}=0.98 \quad \mathrm{~F}=275 \quad \mathrm{DW}=1.8 \\
& \ln X E_{I N D i, t}=-18.3+1.7 \ln Y_{I N D i, t}-0.37 \ln M E_{T H A, t}+0.65 \ln \boldsymbol{M E} E_{T H A ~ i, t-I} \\
& \begin{array}{llll}
-0.86 & 1.9 & -0.4 & 1.4
\end{array} \\
& \bar{R}^{2}=0.92 \quad \mathrm{~F}=39 \quad \mathrm{DW}=2.2 \\
& \ln M E_{. I N D i, t}=-8.7+1.3 Y E_{, t}+0.26 M E_{. I N D} i, t-1 \\
& \begin{array}{lll}
4.01 & 4.2 & -0.22
\end{array} \\
& \bar{R}^{2}=0.92 \quad \mathrm{~F}=151 \quad \mathrm{DW}=1.5
\end{aligned}
$$

The results of the equation 8 suggest that the growth in INDIA's income exerts a positive influence on UAE's exports to India. This is clear from to gradually high to value of the coefficient $Y$, IND,t, . Hence, an increase in India's GDP results in an increase in India's imports from UAE. . This is also clear from the low $\mathrm{t}$ values of the coefficients $\beta_{2}$ and $\beta_{3}$ in the $\mathrm{X} E_{-I N D,}$ t equation, which suggest the absence of feedback effect.

The regression results in the equation 9 suggest that UAE imports from India are positively related to the UAE GDP within the absence of partial adjustment mechanism. The short-term elasticity of UAE imports from india. with respect to UAE income is approximately 1.36 , while its long-term counterpart is approximately 1.83. This suggests that an increase in UAE income by $1 \%$ results in an increase in UAE imports from India. by approximately $136 \%$ in the short term and by $183 \%$ in the long term.

The regression results for China are given in equation 10 -12. These results in equation 10 would suggest that UAE income is not related to UAE exports to China and to the rest of the world. An examination of the coefficient $\left(Y E_{, t-1}\right)$ further suggests the existence of a significant spread effects.

The results of the equation 11 suggest that the coefficient of $\boldsymbol{X E}$, , China, $t$ variable is the key determinant of UAE exports to China while the china's income does not have any significant impact on UAE exports to China. The high t value of the coefficient $B_{2}$ suggest that existence of a partial feedback effect.

$$
\begin{aligned}
& \ln Y E_{, t}=1.2+.006 \ln X E_{\text {. China }, t}+.51 \ln X E_{, 0, t}+.35 \ln Y_{E, t-1} \\
& \begin{array}{llll}
0.24 & 0.14 & 0.52 & 1.5
\end{array} \\
& \bar{R}^{2}=0.98 \quad \mathrm{~F}=243 \quad \mathrm{DW}=1.7 \\
& \ln X E_{\text {Chin }, t}=-3.5+0.13 \ln Y_{\text {Chin }, t}+1.53 \ln \boldsymbol{M} \boldsymbol{E}_{\text {Chin it }}-0.58 \ln \boldsymbol{M} \boldsymbol{E}_{\text {Chin }, t-1} \\
& \begin{array}{llll}
-0.45 & 0.17 & 3.8 & -1.7
\end{array} \\
& \bar{R}^{2}=0.94 \quad \mathrm{~F}=50.8 \quad \mathrm{DW}=2.3 \\
& \text { In } M E_{\text {. China } i, t}=-8.7+1.4 Y E_{, t}+0.13 M E_{\text {. China } i, t-1} \\
& \begin{array}{lll}
-3.7 & 4.1 & 0.57
\end{array} \\
& \bar{R}^{2}=0.94 \quad \mathrm{~F}=92 \quad \mathrm{DW}=1.6
\end{aligned}
$$

The regression results in the equation 12 suggest that UAE imports from China are positively related to the UAE GDP. The short-term elasticity of UAE imports from China with respect to UAE income is approximately 1.4, while its long-run counterpart is approximately 1.6. This suggests that an increase in UAE income by $1 \%$ results in an increase in UAE imports from China by approximately $140 \%$ per cent in the short term and $160 \%$ in the long term.

\section{CONCLUSION}

Paper applied a simultaneous equation model in order to detect if there is any feedback effect in the trade relationship between UAE and its three top trading partners. The model is estimated using the Two Stage Least Squares (2SLS) procedure of estimation and the major outcomes can be summarised as follows:

UAE GDP appears to be greatly affected by its export to Japan. The coefficient of the lagged GDP variable of UAE is statistically significant at five per cent level in all cases which suggest the existence of a strong spread effects from the export sector to the rest of the UAE economy. the GDP of UAE's trading partners is a major determinant of UAE exports to only Japan.

There is evidence of partial feedback effect in UAE trade with each of Japan and China.

There is a high degree of concentration of UAE imports from particular geographical area. Over 65 percent of UAE's imports are supplied by Asian countries.

UAE's imports from its partner are subject to a partial adjustment mechanism. The short-term elasticity of UAE imports from its top trading partners with respect to its income seems to be higher (e.g. ranging from .55 to 1.8) in all cases. This would suggest that UAE income has a strong impact on its imports from its top trading partners.

\section{REFERENCES}

[1] M. M. Metwally and Y. R. Vadlamudi, "Trade Relationship Between Australia Middle Eastern Countries," The Middle East Business and Economic Review, vol. 4, no. 2, 1992, pp. 13-22

[2] M. H. Ardakani, Trade Relatinship Between Iran and Its Major Trading Partners, 1996.

[3] M. Rammadhan, The effects of the fluctuations in oil prices on the balance of payments of the GCC countries, University of Wollongong, 1999.

[4] A. F. Yahia, M. M. Metwally, and A. S. Saleh, "Impact of fluctuation in oil prices on Libyan trade with its major trading partners," conference On Business, Environment, International Competitiveness 
and sustainable Development of the Asia Pacific Economies, vol. 3-4 December 2007, Monash university, Malaysia, 2007.

[5] M. M. Metwally, "Trade relationships between Saudi Arabia and Japan," Journal of Administrative Sciences, vol. 13, no. 1, 1988, pp. 3-16.

[6] W. E. Griffiths, R. C. Hill, and G. G. Judge, Learning and Practicing Econometrics, New York, J. Wiley and Sons, 1993.

[7] A. H. Studenmund, Using Econometrics A Practical Guide, Boston, Addison Wesley, 2000.

[8] D. Gujarati, Basic Econometrics, $4^{\text {th }}$ Ed, McGraw-Hill, New York, 2003.

[9] R. S. Pindyck and D. L. Rubinfeld, Econometric Models and Economic Forecasts, Boston: McGraw-Hill, 1998.

[10] D. Salvatore and D. Reagle, Statistics and Econometrics, $2^{\text {nd }} . e d$. New York, McGraw-Hill, 2002

[11] AMF. Foreign Trade Statistics. [Online]. Available: http://www.amf.org.ae/pages/

[12] IMF, Direction of Trade Statistics Yearbook, Various issues, Washington, DC

[13] Unite Nations (2012). Country Profile- Statistics Division. [Online]. Available: http://unstats.un.org/unsd/snaama/Introduction.asp

[14] A. F. Yahia and M. M. Metwally, "Impact of Fluctuations in Oil Prices on Investment in the Libyan Economy," Global Review of Business and Economic Research, vol. 3, no. 1, 2007, pp. 1-12

[15] Ramanathan Ramu, Introductory Economics with Applications, New York, Harcourt Brace College, 1998.

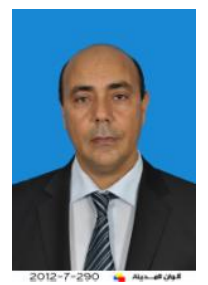

Dr. Abdusalam F Yahia is with department of economics, Faculty of Economics and Commerce Almergibe University, Al- Kumis, Libya. He completed his Ph.D. degree in Economics at the University of Wollongong, Australia, 2005- 2008. He is currently teaching econometrics at the Faculty of Economics and Commerce Almergibe University, Al- Kumis, Libya. He holds 10 years of experience in teaching undergraduate classes and 5 years in teaching postgraduate classes. He has published in refereed international journals (e.g. Global Review of Business and Economic Research; The Middle East Business and Economic Review). He also, has presented many papers in international conferences in different area of the worldwide (e.g. New Zealand, Malaysia, Australia and Sultanate of Oman). His current research interests concentrate on the areas of Applied Economics, principle and advanced econometric methods, the issue of oil prices fluctuations, Economic Growth, Foreign Direct Investment and Trade Relationships (with emphasis on the Middle East and North Africa regions). 